DOI https://doi.org/10.36059/978-966-397-237-4-8

Рябовол Л. Т.,

доктор педагогічних наук, професор, професор кафедри державно-правових дисциплін та

адміністративного права

Центральноукраӥнського державного педагогічного університету імені Володимира Винниченка,

м. Кропивницький

\title{
СИСТЕМА АНТИДИСКРИМІНАЦІЙНОГО ЗАКОНОДАВСТВА УКРАЇНИ
}

Анотація. $у$ розділі визначено поняття та елементи дискримінації, сутність принципу недискримінації. Антидискримінаційне законодавство України розглянуто як систематизовану сукупність (систему) актів різного правового характеру, а саме вітчизняних нормативно-правових актів різної юридичної сили (Конституція України, Закони Украӥни, підзаконні акти) та міжнародних документів, ратифікованих Україною. Міжнародні акти нині досліджено як узгоджений комплекс, що охоплює документи ООН, акти Ради Європи та акти ЄС. Встановлено, що особливе місце у цьому комплексі посідає практика ЄСПЛ, врахування якої $\epsilon$ обов'язковим для національних судів у процесі розгляду справ відповідної категорії. Констатовано, що ступінь імплементації основних положень цих документів зумовлює рівень ефективності вітчизняного законодавства про запобігання та протидію дискримінації. Окреслено напрями його удосконалення.

\section{Вступ}

Підвищення ефективності діяльності 3 утвердження й забезпечення прав та свобод людини i громадянина, налагодження дієвих механізмів їх реалізації, гарантування й захисту - пріоритетний напрям функціонування сучасної демократичної, соціальної, правової держави. Забезпечення прав та свобод людини як першочергове завдання разом із завданнями щодо зміцнення національної безпеки, подолання економічної та екологічної кризи, реформування державного управління залишається головним обов'язком держави та має 
визначати зміст і спрямованість їі діяльності, що зазначено в Національній Стратегії у сфері прав людини (далі - Стратегія). Забезпечення пріоритетності прав і свобод людини позиціонується у цьому документі як визначальний чинник формування та реалізації державної політики, здійснення повноважень органів державної влади та місцевого самоврядування, ведення господарської діяльності. Значення Стратегії нині полягає в тому, що вона спрямована на об'єднання суспільства 3 питань розуміння цінностей прав і свобод людини, забезпечення й захист яких здійснюється на основі принципів рівності та недискримінації [30].

Перелік прав та свобод, закріплений у Конституції України, $\epsilon$ ширшим, ніж такі переліки у Конвенції про захист прав та основоположних свобод і Хартії основних прав $€ C$ разом, що встановила М.О. Фокіна [39, с. 11], однак у контексті їх забезпечення актуальною залишається проблема дискримінації. Як справедливо зазначає 3.П. Равлінко, найбільш яскраво дискримінація проявляється в тих відносинах, у яких сторони фактично нерівні, зокрема у трудових, адміністративно-правових відносинах між особами та органами державної виконавчої влади [23, с. 92]. Факти дискримінації $\epsilon$ в нашому повсякденному та професійному житті, приватній та публічній сферах, проте багато людей не помічають їх, отже, не кваліфікують як такі, на що вказує Т. Фулей $[22$, с. 5]. Якзазначено у звіті «Вирішення проблеми дискримінації та нерівності в Україні», «реалії дискримінації та нерівності $є$ такими, що їхні прояви так само численні і різноманітні, як і населення України. Кожна людина матиме власний досвід дискримінації та нерівності, що виникають у різних сферах життя, в різних обставинах, у взаємодії з різними особами, установами чи організаціями і в результаті будь-якого аспекту її ідентичності або будь-якої комбінації цих аспектів» [3, с. 16].

Вирішення проблеми дискримінації вимагає вжиття комплексу заходів із запобігання та протидії цьому ганебному явищу. План дій з реалізації Національної стратегії у сфері прав людини на 2021-2023 роки (далі - План дій) передбачає вжиття відповідних заходів у таких напрямах, як удосконалення вітчизняного законодавства у сфері забезпечення прав людини, зокрема подальше приєднання України до міжнародних договорів щодо заборони дискримінації; підвищення кваліфікації суддів, прокурорів, поліцейських, державних службовців 3 питань 
застосування антидискримінаційного законодавства; проведення інформаційно-просвітницької роботи щодо прав людини, механізмів їх реалізації, захисту та відновлення [28]. Виходячи з § 8 «Запобігання та протидія дискримінації» Стратегії, зазначаємо, що саме удосконалення законодавства України у сфері запобігання та протидії дискримінації є обов'язковою умовою ефективного вирішення цієї проблеми [30]. Не можна не погодитися з твердженням С. Ковбасюка про те, що саме недосконалість/ недієвість антидискримінаційного законодавства - одна з перешкод на шляху європейської інтеграції України [11, с. 259].

Антидискримінаційне законодавство, у тому числі національні й міжнародні акти та відповідна практика Європейського Суду 3 прав людини (далі - ЄСПЛ), були предметом досліджень фахівців з різних юридичних наук, зокрема теорії та історії держави і права, конституційного, адміністративного, трудового, кримінального, міжнародного права. Відповідний аналіз переважно в контексті вивчення сутності принципу недискримінації проводили О.-М. Бачинська, О.Р. Дашковська, Н.В. Дрьоміна-Волок, О.С. Калмикова, В.В. Лемак, Р.Я. Мандель, Ю.К. Мороз, Л.О. Нікітенко, 0.З. Панкевич, С.П. Погребняк, Г.О. Христова, С.В. Шевчук та інші науковці. Загалом це питання досліджено достатньо грунтовно, проте у доступних нам наукових працях повною мірою не реалізовано системний підхід, чим зумовлені тема й мета наукової роботи, що полягає в розгляді національного антидискримінаційного законодавства як комплексу актів різного характеру та юридичної сили. Саме забезпечення комплексності законодавства у сфері запобігання та протидії дискримінації з урахуванням найкращого міжнародного, у тому числі європейського, досвіду та реальних викликів у сфері прав і свобод людини в Україні позиціонується в Стратегії як одне з важливих завдань у цій сфері, в основу розв'язання якого, крім інших, мають бути покладені заснований на правах людини та антидискримінаційний підходи [30].

\section{1. Права та свободи людини. Дискримінація. Принцип недискримінації. \\ Антидискримаційне законодавство як система}

Як явище соціального й політико-правового життя права та свободи людини пройшли тривалий і складний шлях свого становлення, однією з детермінант якого була й залишається 
дискримінація. Більш того, за різних історичних умов та обставин саме дискримінаційні підходи держава стимулювала і як активний розвиток прав та свобод людини, і як легалізацію цього інституту, тобто визнання офіційного факту їх існування та юридичне закріплення. У результаті узагальнення конституційної практики зарубіжних країн М.О. Фокіна дійшла висновку, що концепція прав людини в кожній 3 них формувалася під впливом відповідної культури, релігії, моралі, філософії, отже, не може бути єдиною для всіх держав і суспільств, тому посідає особливе місце у світовій правовій культурі. Ця концепція виникла в західних країнах та знайшла своє закріплення в їх конституціях. Нині ідея прав людини є універсальною і набула поширення практично в усіх державах, як правило, з урахуванням відповідної національної своєрідності [39, с. 8].

Права та свободи людини вже були предметом наших досліджень. У попередніх працях права та свободи, зокрема конституційні, визначено нами як закріплені в Конституції та гарантовані державою можливості кожної людини і громадянина вільно й самостійно вибирати вид і міру своєї поведінки, користуватися наданими соціальними благами в особистих та загальних інтересах; $є$ основою конституційно-правового статусу. До їх суттєвих ознак віднесено те, що вони життєво важливі й необхідні як для окремої людини, так і для нормального функціонування суспільства й держави; закріплюються за кожною людиною; рівні та єдині для всіх; мають найвищий юридичний захист; реалізуються за певним механізмом тощо [35, с. 17].

Інститут прав та свобод людини - один з основних інститутів як конституційного права України, так і державного права зарубіжних країн. Поділяємо наукову позицію М.О. Фокіної, що інститут прав та свобод людини - система базових норм i принципів, які закріплені на конституційному і законодавчому рівнях, встановлюють правовий статус особи, регулюють їі відносини 3 державою та гарантують права особи в цих відносинах. Погоджуємося з висновком ученої, що цей інститут $\epsilon$ комплексним, а його складовими частинами $\epsilon$ норми, які визначають основні права та свободи людини й громадянина, їх види, механізми реалізації та гарантування [39, с. 5, 9].

За сферою життя та діяльності особи, змістом (характером) суспільних відносин, у які особа може вступати, конституційні права і свободи традиційно поділяються на особисті, політичні, 
соціально-економічні та культурні. Основу системи конституційних прав і свобод людини й громадянина закладають особисті права (права людини). В державному праві зарубіжних країн їх поділяють на такі, що захищають людину від свавілля з боку інших осіб, і ті, які захищають їі від свавілля 3 боку держави, хоча такий поділ $є$ умовним. Політичні права належать переважно громадянину, тобто особі як члену певного політичного співтовариства. Основним серед них $\epsilon$ виборче право - право обирати і бути обраним до органів державної влади та органів місцевого самоврядування, яке дає змогу особі брати участь в управлінні суспільними й державними справами. Соціально-економічні права визначають можливості людини і громадянина в соціальній та економічній сферах. Фундаментальним, на якому грунтуються всі інші права цієї групи, $\epsilon$ право на приватну власність [34, с. 175, 176]. Культурні права це можливості доступу особи до культурних, духовних надбань, цінностей свого народу та усього людства, чим забезпечується вільний культурний розвиток особистості.

Нині обгрунтованим видається твердження В.Б. Ковальчука про те, що права людини є критерієм легітимності державної влади. Як невідчужувані вони $\epsilon$ засобом контролю i самообмеження влади, постають як незалежні стандарти, дотримання/недотримання державою яких $\epsilon$ підставою для критики державних інституцій та законодавства громадянським суспільством, як вважає вчений, та підсумовує, що якщо держава нехтує правами і свободами людини, то вона втрачає легітимність, як і акти, видані нею [10, с. 335].

Потенційно носії названих прав у процесі їх реалізації можуть зазнавати неправомірних посягань, різноманітних утисків. Отже, недостатньо задекларувати права й свободи навіть на найвищому конституційному рівні, держава має їх гарантувати, тобто створити систему умов і засобів, власне гарантій, необхідних і достатніх для реалізації кожною особою своїх конституційних прав і свобод. Відповідна система має охоплювати економічні, політичні, організаційні та правові гарантії. У рамках нашого дослідження зупинимось безпосередньо на правових. Основним серед них $\epsilon$ конституційний принцип, закріплений у ст. 3 Конституції України, згідно 3 яким «людина, іï життя і здоров'я, честь і гідність, недоторканність i безпека визнаються в Україні найвищою соціальною цінністю. Права і свободи людини та їх гарантії 
визначають зміст і спрямованість діяльності держави». Істотним $\epsilon$ значення наступних конституційних приписів: «усі люди $€$ вільними і рівними у своїй гідності та правах» (ст. 21); «громадяни мають рівні конституційні права і свободи та $є$ рівними перед законом; не може бути привілеїв чи обмежень за ознаками раси, кольору шкіри, політичних, релігійних та інших переконань, статі, етнічного та соціального походження, майнового стану, місця проживання, за мовними або іншими ознаками» (ст. 24) [18]. Як видно з наведених норм, в Основному Законі не використовується термін «дискримінація», однак прямо вказується на недопустимість привілеїв та обмежень, що загалом відповідає міжнародним актам у сфері прав людини, у тому числі щодо рівності.

Слід акцентувати увагу на тому, що свобода й рівність як основні принципи правового статусу людини знайшли своє закріплення в конституціях майже всіх держав світу. При цьому як юридична категорія рівність має декілька аспектів, таких як рівність прав і свобод кожної людини; рівність усіх перед законом; рівність усіх перед судом [34, с. 176]. Рівність прав і свобод означає, що всі люди мають однаковий (рівний) їх обсяг, права та свободи однаковою мірою належать усім особам незалежно від статі, раси, політичних, релігійних, інших переконань, етнічного, соціального походження, майнового стану тощо. Рівність усіх перед законом і судом передбачає, що всі положення законодавства однаковою мірою поширюють свій нормативний вплив на кожну особу, у тому числі, під час здійснення судочинства.

Результати аналізу міжнародних актів щодо забезпечення прав людини будуть викладені у $\S 2$, зараз лише заначимо, що принцип заборони дискримінації (недискримінації) позиціонується в них у взаємозв'язку з принципом рівності всіх осіб перед законом та рівного захисту за законом, тому переважно ці принципи вчені розглядають у сув'язі. У науковій літературі репрезентовано різні підходи до їх співвідношення, а саме принцип недискримінації ототожнюють 3 принципом рівності; перший розглядають як похідний від другого; обстоюють самодостатність цих принципів. 0.3. Панкевич, наприклад, вважає, що вимога недискримінації $€$ складовою частиною загальноправової засади рівності, яка, однак, не вичерпується лише цією вимогою, оскільки необхідність диференціації юридичного регулювання покликана також забезпечувати фактичну («повну й реальну») рівність [21, с. 327]. 
На думку О.-М. Бачинської, ці принципи різняться за своєю сутністю. Так, якщо принцип рівності - це забезпечення рівних умов для реалізації особою належних їй прав, свобод і обов'язків, то принцип недискримінації - це неприпустимість обмеження прав та свобод людини у зв'язку з ії соціальними чи антропологічними якостями [2, с. 167]. В будь-якому разі не можна не погодитися із думкою 3.П. Равлінко про те, що принципи правової рівності й заборони дискримінації тісно взаємопов'язані, доповнюють один одного, позаяк правова рівність - основа правового статусу учасників суспільних відносин, а заборона дискримінації як принцип - додаткова гарантія правової рівності [32, с. 86]. Нині слід акцентувати увагу на тому, що принцип рівності необхідно відрізняти від принципу рівного ставлення, проголошеного у багатьох документах $€$.

У звіті/доповіді «Вирішення проблем дискримінації та нерівності в Україні» репрезентовано уніфіковану систему прав людини щодо рівності, в рамках якої невід'ємною у здійсненні всіх прав людини $\epsilon$ рівність. Ця система покликана подолати фрагментацію в законодавстві та політиці з питань рівності. Ї̈̈ репрезентовано як цілісний комплекс нерівностей, у якому кожний тип нерівності $\epsilon$ унікальним, водночас різні типи нерівностей мають загальні аспекти. В рамках цієї системи інтегровано такі типи нерівності, як нерівності за ознаками раси, статі, релігії, інвалідності, стану здоров'я (зокрема, ВІЛ-статус), сексуальної орієнтації та гендерної ідентичності, етнічної приналежності, національного походження і кольору шкіри, національності та громадянства, мови, релігії, віку (зокрема, уразливий стан дітей), а також дискримінація за сукупністю/ множинністю ознак; у різних сферах життя - політичній, соціально-економічній, культурній, у тому числі сферах зайнятості, освіти, надання товарів і послуг; статусні та соціальноекономічні нерівності [3, с. 2, 29]. У ст. 4 Закону України «Про засади запобігання та протидії дискримінації в Україні» визначено такі сфери суспільних відносин, у яких можливі прояви дискримінації, як громадсько-політична діяльність; державна служба та служба в органах місцевого самоврядування; правосуддя; трудові відносини, у тому числі щодо застосування роботодавцем принципу розумного пристосування; охорона здоров'я; освіта; соціальний захист; житлові відносини; доступ до товарів і послуг; інші сфери [27]. 
В Академічному тлумачному словнику української мови дискримінація - це обмеження або позбавлення прав певних категорій громадян за расовою або національною належністю, політичними й релігійними переконаннями [1, с. 284]. Відповідно до ч. 2 ст. 1 Закону України «Про засади запобігання та протидії дискримінації в Україні», дискримінацією «є ситуація, за якої особа та/або група осіб за їх ознаками раси, кольору шкіри, політичних, релігійних та інших переконань, статі, віку, інвалідності, етнічного та соціального походження, громадянства, сімейного та майнового стану, місця проживання, мовними або іншими ознаками, які були, $\epsilon$ та можуть бути дійсними або припущеними, зазнає обмеження у визнанні, реалізації або користуванні правами і свободами в будь-якій формі, встановленій цим Законом, крім випадків, коли таке обмеження має правомірну, об'єктивно обгрунтовану мету, способи досягнення якої $\epsilon$ належними та необхідними» [27].

Загалом дискримінація - це неправове обмеження прав особи за умов відсутності його розумного виправдання та неспівмірності з метою у зв'язку з віком, статтю, кольором шкіри, політичними чи релігійними переконаннями, соціальним станом, іншими підставами, які постають як дискримінаційні ознаки, мотиви. Елементами дискримінації $\epsilon$ відмінне ставлення будь-якого прояву; негативний характер; завдання суб'єкту шкоди; значуща ознака, яка в конкретній ситуації постає як дискримінаційна; відсутність суспільно необхідної мети. Отже, дискримінація $є$ тоді, коли суб'єкт зазнав шкоди внаслідок особливого/відмінного негативного ставлення будь-якого характеру за дискримінаційною ознакою без об'єктивного й достатнього обгрунтування, що суперечить суспільній необхідності.

Як явище дискримінація має два аспекти, зазначає 3.П. Равлінко, а саме негативний (негативна дискримінація) необгрунтоване, упереджене і свавільне ставлення до особи, що призводить до порушення основних прав; позитивний (позитивна дискримінація) - різне ставлення у зв'язку з об'єктивною нерівністю певних суб'єктів у суспільному житті задля забезпечення їх формальної рівності [32, с. 52, 55-56, 96]. У цьому контексті логічним видається виокремлення двох видів відповідальності держави перед людиною у разі порушення ії прав і свобод, а саме негативної, яка полягає в обов'язку держави компенсувати людині збитки (матеріальні, моральні), завдані 
порушенням iї прав і свобод державними органами та/або їх посадовими особами; позитивної, за якої держава повинна створювати умови, необхідні для реалізації і захисту прав та свобод людини (В.А. Троян) [38, с. 232].

Акцентуємо увагу на позитивній дискримінації. За визначенням Г.О. Христової, це вжиття спеціальних юридичних заходів (позитивних дій), які спрямовані на усунення дисбалансу між можливостями різних категорій осіб щодо реалізації рівних прав, зумовленого наявністю в суспільстві усталених стереотипів, практик чи традицій; виконують функцію правової компенсації для певних осіб/категорій осіб задля ліквідації наслідків соціальної нерівності [41, с. 14]. У ч. 5 ст. 1 Закону України «Про засади запобігання та протидії дискримінації в Україні» позитивні дії визначено як спеціальні тимчасові заходи, що мають правомірну, об'єктивно обгрунтовану мету, спрямовану на усунення юридичної чи фактичної нерівності у можливостях для особи та/або групи осіб реалізовувати на рівних підставах права і свободи, надані їм Конституцією і законами України. Застосування позитивних дій у ст. 7 того ж Закону віднесено до основних напрямів державної політики щодо запобігання та протидії дискримінації разом із недопущенням дискримінації, створенням умов для своєчасного виявлення фактів дискримінації та забезпечення ефективного захисту осіб та/або груп осіб, які постраждали від неї, а також вихованням і пропагандою серед населення поваги до осіб/груп осіб незалежно від їх певних ознак [27].

У ст. 2 того ж Закону визначено сутність принципу недискримінації, яка виявляється в тому, що незалежно від певних ознак осіб та/або груп осіб, їм має бути забезпечено рівність прав та свобод; рівність перед законом; повагу до гідності кожної людини; рівні можливості. Той самий Закон оперує також терміном «заборона дискримінації», сутність якого у ст. 6 теж розкривається через категорії «рівні права і свободи» та «рівні можливості для їх реалізації», що їх повинні мати всі особи незалежно від певних ознак відповідно до Конституції України, загальновизнаних принципів і норм міжнародного права та міжнародних договорів України [27]. Аналіз наведених положень дає підстави стверджувати, що законодавець чітко не розмежовує принцип недискримінації та заборону дискримінації, скоріше, використовує відповідні категорії як синонімічні. 
Щодо національного антидискримінаційного законодавства як системи зазначимо, що питання системи законодавства урізних сферах уже були предметом наших досліджень. Так, систему законодавства про наукову і науково-технічну діяльність нами розглянуто як цілісну, ієрархічну сукупність взаємоузгоджених і таких, що доповнюють і розвивають положення один одного, нормативно-правових актів, а саме Конституції України, Законів України, підзаконних актів, міжнародних i регіональних актів, міжнародних договорів України [36, с. 4]; систему законодавства про правову освіту населення України як систематизовану сукупність нормативно-правових актів різної юридичної сили, складниками якої $\epsilon$ Конституція України, Закони України, підзаконні нормативно-правові акти, міжнародні і регіональні акти [37, с. 38].

Досліджуючи антидискримінаційне законодавство, вважаємо доцільним реалізувати аналогічний підхід, що повною мірою узгоджується з приписами Закону України «Про засади запобігання та протидії дискримінації в Україні», згідно зі ст. 3 якого «законодавство про запобігання та протидію дискримінації складається 3 Конституції України, цього Закону та інших нормативно-правових актів. Якщо міжнародним договором України, згода на обов'язковість якого надана Верховною Радою України, встановлено інші правила, ніж ті, що передбачені цим Законом, застосовуються правила міжнародного договору» [27]. Вважаємо, що наведене визначення потребує вдосконалення щодо складників антидискримінаційного законодавства, та пропонуємо розглядати його як систематизовану сукупність вітчизняних нормативно-правових актів різної юридичної сили, а також міжнародних, у тому числі європейських, документів, ратифікованих Україною, адже, відповідно до ч. 1 ст. 9 Конституції України, «чинні міжнародні договори, згода на обов'язковість яких надана Верховною Радою України, $\epsilon$ частиною національного законодавства України» [18], а згідно зі ст. 2 Закону України «Про міжнародні договори України», міжнародним договором України $\epsilon$ документ, укладений у письмовій формі з іноземною державою або іншим суб'єктом міжнародного права, який регулюється міжнародним правом; міжнародним $є$ договір України незалежно від того, міститься він в одному чи декількох пов'язаних між собою документах, а також від його конкретного найменування (договір, угода, конвенція, пакт, протокол тощо) [29]. 


\section{2. Міжнародні акти як правова основа становлення системи антидискримінаційного законодавства України}

Передусім звернемося до Загальної декларації прав людини документа, який $є$ осередком формування системи міжнародних актів щодо забезпечення прав та свобод людини. Дискримінація у ньому розглядається на таких різних рівнях:

- загальний рівень; так, у ст. 2 зазначено, що кожна людина повинна мати всі права і всі свободи, проголошені Декларацією; нині визначено дві групи відповідних критеріїв, а саме певні риси самої особи (раса, колір шкіри, стать, мова, релігія, політичні або інші переконання, національне чи соціальне походження, майнове або інше становище); статус (політичний, правовий, міжнародний) країни або території, до якої людина належить (чи $\epsilon$ ця територія незалежною, підопічною, несамоврядованою або інакше обмеженою у своєму суверенітеті); незалежно від конкретної ознаки особи або статусу території не повинно проводитися ніякого розрізнення; у ст. 7 наголошено на тому, що всі люди є рівними перед законом і мають право без будь-якої різниці на рівний захист законом, а також право на рівний захист від будь-якої дискримінації і будь-якого підбурювання до неї;

- рівень окремих прав; так, згідно зі ст. 23, кожна людина без будь-якої дискримінації має право на працю, вільний вибір роботи, справедливі і сприятливі умови праці, захист від безробіття, рівну оплату за рівну працю;

- рівень окремих прав і визначених категорій осіб, зокрема, відповідно до ст. 16, чоловіки і жінки, які досягли повноліття, без будь-яких обмежень за ознакою раси, національності або релігії мають право одружуватися і засновувати сім'ю, при цьому вони користуються однаковими правами щодо одруження під час шлюбу та під час його розірвання [8].

До документів ООН, які становлять частину антидискримінаційного законодавства України, належать також Міжнародна конвенція про ліквідацію всіх форм расової дискримінації (ратифікована Україною 21 вересня 1969 року), Конвенція про ліквідацію всіх форм дискримінації щодо жінок (ратифікована 12 березня 1981 року), Конвенція про права осіб з інвалідністю (ратифікована 16 грудня 2009 року), Конвенція про права дитини (ратифікована 27 лютого 1991 року) тощо.

Під расовою дискримінацією $\mathrm{OOH}$ розуміє будь-яке розрізнення, виняток, обмеження чи перевагу, що грунтується на 
ознаках раси, кольору шкіри, родового, національного чи етнічного походження, мета/наслідок яких полягає у знищенні або применшенні визнання, використання чи здійснення на рівних засадах прав людини та основних свобод у політичній, економічній, соціальній, культурній, інших галузях суспільного життя. Держави-учасниці Конвенції про ліквідацію всіх форм расової дискримінації мають засуджувати такі дії та всіма можливими способами проводити політику ліквідації всіх форм расової дискримінації, а також сприяти взаєморозумінню між усіма расами [20].

У Конвенції щодо дискримінації в галузі праці та занять МОП дискримінація також тлумачиться як «будь-яке розрізнення, недопущення або перевага, що робиться за ознакою раси, кольору шкіри, статі, релігії, політичних переконань, іноземного походження або соціального походження i призводить до знищення або порушення рівності можливостей чи поводження в галузі праці та занять» [17].

Конвенція про ліквідацію всіх форм дискримінації щодо жінок популяризує модель «дійсної рівності», елементами якої $\epsilon$ рівність можливостей щодо рівного доступу жінок до всіх ресурсів країни, що має гарантуватися законодавством i політикою держави та забезпечуватися відповідними механізмами й інститутами; рівність у доступі до можливостей, тобто держава зобов'язана забезпечити відсутність перешкод щодо реалізації жінками своїх прав; рівноцінність результатів (показником ефективності виконання державами-учасницями цієї Конвенції $є$ те, наскільки дії влади приводять до реальної зміни становища жінок) [22, с. 77-78].

Дискримінація за ознакою інвалідності, відповідно до Конвенції про права осіб з інвалідністю, - це будь-яке розрізнення, виключення чи обмеження з причини інвалідності, метою або наслідком якого $\epsilon$ применшення або заперечення визнання, реалізації або здійснення нарівні з іншими всіх прав людини й основоположних свобод у політичній, економічній, соціальній, культурній, цивільній чи будь-якій іншій сфері [13].

У ст. 2 Декларації про ліквідацію всіх форм нетерпимості та дискримінації на основі релігії чи переконань зазначено, що ніхто не повинен піддаватися дискримінації на основі релігії або переконань з боку будь-якої держави, установи, осіб або груп осіб. Нетерпимість та дискримінація на основі релігії чи переконань 
у цьому документі визначено як будь-яке розрізнення, виняток, обмеження або надання переваги, яке грунтується на релігії або переконаннях та має на меті або своїм наслідком знецінення/ зменшення визнання, використання або здійснення на основі рівності прав людини та основних свобод [5].

Ухвалюючи Конвенцію про боротьбу з дискримінацією в галузі освіти, $\mathrm{OOH}$ виходила з того, що у цій галузі необхідним $\epsilon$ викорінення будь-якої дискримінації, а також заохочення рівних можливостей для всіх та рівного до всіх ставлення. У ст. 1 цього документа дискримінацію визначено, як і у згаданих вище актах $\mathrm{OOH}$, як таку, що охоплює будь-яке розрізнення, виняток, обмеження або надання переваги за ознаками раси, кольору шкіри, статі, мови, релігії, політичних або інших переконань, національного або соціального походження, економічного стану або народження, що має на меті або своїм наслідком порушення рівності у відносинах в галузі освіти, при цьому йдеться про всі типи та ступені освіти, доступ до освіти, якість та умови навчання [16].

Як бачимо, у документах ООН дискримінація незалежно від ознаки, за якою вона здійснюється, розглядається як розрізнення, метою та/або наслідком якого $\epsilon$ порушення рівності, рівних можливостей.

Антидискримінаційні норми Загальної декларації прав людини та Конвенцій ООН своє логічне продовження і закріплення знайшли в документах Ради Європи (далі - Р€), передусім Конвенції про захист прав людини і основоположних свобод (далі - ЄКПЛ) (ратифікована Україною 17 вересня 1997 року). Виходячи зі ст. 14 «Заборона дискримінації» цього акта, зазначаємо, що користування правами та свободами, визнаними в ній, має забезпечуватися без дискримінації незалежно від таких ознак, як стать, раса, колір шкіри, мова, релігія, політичні чи інші переконання, національне чи соціальне походження, майновий стан, належність до національних меншин [12].

Закріплення $\mathrm{P} Є$ антидискримінаційних вимог на конвенційному рівні $\epsilon$ надзвичайно важливим кроком на шляху формування системи відповідного європейського законодавства. Водночас не можна не погодитися зі вченими, які вказують на недоліки ЄКПЛ як джерела антидискримінаційного законодавства. 0.3. Панкевич, наприклад, справедливо зазначає, що цей акт не містить визначення поняття дискримінації, а його тлумачення ускладнено 
тим, що офіційні (франкомовний та англомовний) варіанти тексту цього акта мають термінологічні розбіжності у формулюванні статті 14. Остання також не містить загальної заборони дискримінації, обмежуючись метою забезпечення користування без дискримінації правами та свободами, закріпленими в ЄКПЛ. Згаданий учений позначає таке формулювання ст. 14 як обмежене, «урізане», що у практиці застосування, передусім у практиці Європейського Суду з прав людини (далі - ЄСПЛ), виявило свою недостатність, «неповноцінність», «несамостійне» значення ст. 14 та спричинило необхідність прийняття Протоколу № 12 до ЄКПЛ [21, с. 333].

У ст. 1 Протоколу № 12 (ратифіковано Україною 9 лютого 2006 року) проголошено загальну заборону дискримінації, продубльовано перелік ознак, закріплених у ст. 14 ЄКПЛ та зазначено, що здійснення будь-якого права, передбаченого законом, забезпечується без дискримінації за цими ознаками, а також акцентовано увагу на тому, що за будь-якою з цих ознак ніхто не може бути дискримінований будь-яким органом державної влади. Виходячи зі змісту цієї статті, зазначаємо, що від сторін вимагається забезпечення без дискримінації за будьякою ознакою прав, передбачених як ЄКПЛ, так і національним законодавством. У цьому Протоколі принцип загальної заборони дискримінації (недискримінації) позиціонується у взаємозв'язку з принципом рівності всіх осіб перед законом та рівного захисту за законом як основоположного принципу [31].

Заборону дискримінації на рівні окремих прав та/або визначених категорій осіб закріплено у спеціальних актах Р€, наприклад, у Рамковій Конвенції про захист національних меншин (ратифікована Україною 9 грудня 1997 року). Виходячи 3 iї змісту, сторони зобов'язуються гарантувати особам, які належать до національних меншин, право рівності перед законом та право на рівний правовий захист, у зв'язку з чим заборонено дискримінацію за ознакою приналежності до національної меншини (ст. 4); вживати заходів для захисту осіб, які можуть стати об'єктами погроз або актів дискримінації, ворожого ставлення чи насильства за ознакою їх етнічної, культурної, мовної або релігійної самобутності (ч. 2 ст. 6); в рамках своїх правових систем забезпечувати, щоб особи, які належать до національної меншини, не дискримінувалися в їх доступі до засобів масової інформації (ст. 9) [33]. 
Складником національного антидискримінаційного законодавства $\epsilon$ також Європейська соціальна хартія (ратифікована Україною 14 вересня 2006 року), у ст. 20 якої закріплено право усіх працівників на рівні можливості та рівне ставлення у вирішенні питань працевлаштування і професії без диск римінації за ознакою статі. Забезпечувати ефективне здійснення цього права сторони зобов'язуються у таких напрямах, як працевлаштування, захист від звільнення, професійна реінтеграція, орієнтація, підготовка, перепідготовка, перекваліфікація; умови працевлаштування і праці, у тому числі винагорода; професійний ріст, просування по службі. У ст. 27 цього акта закріплено право працівників із сімейними обов'язками (жінок та чоловіків, які працюють) на рівні можливості і рівне ставлення до них [7].

Принцип недискримінації проголошено також у ст. 3 Конвенції Ради Європи про заходи щодо протидії торгівлі людьми (ратифікована Україною 21 вересня 2010 року), зокрема передбачено гарантоване вжиття заходів для захисту й підтримки прав жертв без дискримінації за будь-якою ознакою з переліку, закріпленого у ст. 14 ЄКПЛ [15].

Не можна залишити поза увагою Додатковий протокол до Конвенції про кіберзлочинність, який стосується криміналізації дій расистського та ксенофобного характеру, вчинених через комп'ютерні системи (ратифікована 21 липня 2006 року). Виходячи зі ст. 2 документа, зазначаємо, що расистським та ксенофобним є будьякий письмовий матеріал, зображення чи інше представлення ідей/теорій, що захищає, сприяє або підбурює до ненависті, дискримінації чи насильства проти будь-якої особи або групи осіб за ознаками раси, кольору шкіри, національного або етнічного походження, а також віросповідання, якщо вони використовуються як привід для будь-якої з цих дій. Відповідними формами у ст. ст. 4, 5 визначено погрозу та образу з расистських та ксенофобних мотивів. Цим Протоколом сторонам рекомендовано на законодавчому рівні визнати такі дії злочинними та передбачити за їх вчинення кримінальну відповідальність [6].

Однією з останніх, ратифікованих Україною від 20 травня 2020 року, а також такою, що розширила систему вітчизняного антидискримінаційного законодавства, є Конвенція Ради Європи про доступ до офіційних документів, відповідно до ст. 2 якої кожному без дискримінації за будь-якою ознакою за вимогою гарантується право на доступ до офіційних документів, що знаходяться в розпорядженні державних органів [14]. 
Окрему групу актів, спрямованих на боротьбу з дискримінацією, становлять акти Європейського Союзу (далі - ЄС). Акцентуємо увагу на Хартії основних прав Європейського Союзу, ст. 14 «Недопущення дискримінації» якої містить пряму заборону будь-якої дискримінації, зокрема за ознаками статі, раси, кольору шкіри, етнічного або соціального походження, генетичних характеристик, мови, релігії або переконань, політичних або інших поглядів, приналежності до національної меншини, майнового стану, походження, обмеженої працездатності, віку або сексуальної орієнтації [40]. Як видно з документа, ЄC визначає вичерпний перелік ознак як потенційних підстав для дискримінації, на відміну від актів ООН та РЄ, у яких цей перелік не $\epsilon$ вичерпним. Крім того, перелік ознак як підстав для дискримінації в цій Хартії дещо відрізняється від тих, які закріплені у документах ООН та Р€.

Фахівці застерігають, що європейське антидискримінаційне право - це лише на перший погляд єдина загальноєвропейська система правил протидії дискримінації. Воно складається з різних за своїм характером і сутністю компонентів, які виникли в різний час і з різних причин, особливе значення серед яких мають право ЄКПЛ та право ЄС, які взаємодоповнюють одне одного. На наш погляд, достатньо точним і лаконічним $\epsilon$ визначення поняття європейського антидискримінаційного права як сукупності статті 14 ЄКПЛ та Протоколу № 12 до ЄКПЛ, а також антидискримінаційних директив $€ C$, якими забороняється дискримінація в різних контекстах і на різних підставах $[23$, c. $11,12,196]$.

Нині європейське антидискримінаційне право має істотне практичне значення, яке полягає в тому, що національні суди та органи влади можуть посилатися безпосередньо на європейські антидискримінаційні інструменти та практику ЄСПЛ. У розвитку концепції недискримінації в Україні практика ЄСПЛ відіграє особливу роль, більш того, її врахування $\epsilon$ обов'язковим. Так, відповідно до ч. 1 ст. 17 Закону України «Про виконання рішень та застосування практики Європейського суду з прав людини», суди під час розгляду справ як джерело права застосовують ЄКПЛ та практику ЄСПЛ [24].

Узагальнення правових позицій ЄСПЛ щодо дискримінації та принципу недискримінації дало змогу О.Р. Дашковській зробити такі висновки: принцип недискримінації не означає заборону 
різного ставлення під час здійснення прав і свобод, натомість таке різне ставлення має спрямовуватися виключно на коригування фактичної нерівності; дискримінація - це застосування без об'єктивних і розумних підстав різного ставлення до осіб, які перебувають в однаковій ситуації, та однакового ставлення до осіб, які перебувають у різному становищі під час здійснення одного й того ж права, при цьому підставою або мотивом дискримінаційного ставлення є ознаки (закріплені у ст. 14 ЄКПЛ) особи/групи осіб, за якими вони відрізняються від інших осіб/груп осіб [4, с. 124-125]. 0.3. Панкевич теж вказує на те, що в динамічній інтерпретації ЄСПЛ дискримінація розглядається як застосування без об'єктивного чи розумного обгрунтування різного підходу до осіб, які знаходяться в аналогічних ситуаціях, а також однакове поводження з особами, які перебувають в абсолютно різних ситуаціях [21, с. 331].

Саме такий підхід вітчизняні вчені реалізують в авторських визначеннях. Наприклад, принцип недискримінації - загальновизнана норма міжнародного права, сутність якої полягає в забороні різного правового становища людей (володіння ними неоднаковим обсягом прав і свобод), якщо така відмінність заснована на їх природних або соціальних ознаках та/або порушує правову рівність людей як гарантовану державою рівну можливість реалізувати однаковий обсяг прав і свобод (О.С. Калмикова) [9, с. 154]; встановлення в праві заборони на свавільні й необгрунтовані обмеження і переваги за будь-якими ознаками, що може призвести/призводить до порушення основних прав i свобод (З.П. Равлінко) [32, с. 90].

Важливою для України є також вироблена ЄСПЛ доктрина позитивних зобов'язань держави, сутність якої полягає в тому, що держави мають вживати заходів із захисту прав людини, зокрема щодо усунення фактичних та юридичних перешкод у їх реалізації, що, власне, $\epsilon$ ïx позитивними зобов'язаннями. В.В. Лемак та А.Ю. Бадида вказують на те, що ЄСПЛ окреслив межі таких зобов'язань, визначивши відповідні критерії, а саме, виконуючи позитивні зобов'язання, держави мають забезпечувати справедливий баланс між інтересами суспільства загалом та інтересами конкретної особи зокрема; обсяг позитивних зобов'язань держави залежить від конкретної ситуації, яка в ній склалася, зумовлюється ускладненнями, які постали перед неюу сфері управління, зокрема щодо вибору пріоритетів та використання у зв'язку з цим ресурсів; позитивні зобов'язання не 
мають передбачати покладання на органи державної влади нездійсненних або невиправдано складних завдань. У рамках нашого дослідження важливим $\epsilon$ висновок, якого дійшли згадані вчені, а саме з урахуванням права кожної держави на вільний вибір заходів із реалізації позитивних зобов'язань у сфері забезпечення прав людини одним із першочергових завдань нині $\epsilon$ створення законодавства, «яке би втілювало принципи права та спеціалізовані норми національних конституцій і Конвенції, які гарантують права людини», зокрема щодо принципу недискримінації, заборони дискримінації [19, с. 249-250].

Як зазначено у звіті/доповіді «Вирішення проблеми дискримінації та нерівності в Україні», Україна має «дуже хорошу репутацію» щодо міжнародних та європейських угод, «які стосуються прав на рівність і недискримінацію» [3, с. 238, 240]. Підставою для такого твердження $\epsilon$ те, що наша держава ратифікувала велику кількість відповідних актів та активно виконує зобов'язання, які взяла на себе у зв'язку з цим. Водночас у цьому напрямі ще необхідно провести значну роботу. Так, відповідно до Плану дій з реалізації Національної стратегії у сфері прав людини на 2021-2023 роки [28], зокрема, передбачено, що Мінекономіки та МЗС підготують і подадуть Президентові України пропозиції щодо приєднання України до Марракешського договору про полегшення доступу сліпих, осіб з порушеннями зору або іншими обмеженнями з причин інвалідності (іншими обмеженими здібностями) сприймати друковану інформацію до опублікованих творів (про «книги для сліпих»). Його головна мета полягає у встановленні обов'язкових до виконання обмежень і винятків на користь сліпих та осіб з порушеннями зору чи іншими обмеженими здібностями сприймати друковану інформацію. Заплановано також, що Мінсоцполітики, Мін'юст та МЗС підготують пропозиції щодо ратифікації Конвенції Ради Європи про запобігання насильству стосовно жінок і домашньому насильству та боротьбу 3 цими явищами (Стамбульської Конвенції). Передбачено також, що в результаті вивчення питання про можливості ратифікації Конвенції МОП про викорінення насильства та домагання у сфері праці № 190 Мінекономіки, МЗС та Уповноважений Верховної Ради України з прав людини (за згодою) подадуть Кабінетові Міністрів пропозиції щодо ратифікації цієї Конвенції. Крім того, Мін'юст, Мінекономіки, Уповноважений Верховної Ради України з прав людини (за згодою) мають вивчити кращі практики імплементації 
положень Керівних принципів ООН з питань бізнесу та прав людини, Десяти принципів Глобального договору ООН, Рекомендації Rec (2016) Комітету Міністрів Ради Європи в Україні тощо, а також за результатами такого дослідження подати Кабінетові Міністрів України відповідні пропозиції.

Екстраполюючи на наше дослідження висновок М.О. Фокіної щодо умов успішного правового регулювання внутрішньодержавних відносин [39, с. 11], можемо стверджувати, що ефективність національного антидискримінаційного законодавства залежить від того, наскільки узгодженими $\epsilon$ норми власне вітчизняних актів з міжнародними, позаяк останні пропагують пріоритет загальнолюдських цінностей, повагу до прав людини, необхідність підтримувати міжнародний мир, безпеку і демократію.

\section{3. Вітчизняні нормативно-правові акти щодо запобігання}

та протидії дискримінації: сучасний стан і перспективи

Антидискримінаційні положення Конституції України охарактеризовані нами у $\S 1$, отже, у рамках цього параграфу розглянемо звичайне вітчизняне законодавство. Слід зазначити, що вітчизняні акти у сфері запобігання та протидії дискримінації певною мірою узгоджені з міжнародними, закріплюють відповідні цінності, зокрема повагу до прав людини і принцип недискримінації, проте експерти висувають до них деякі зауваження.

Передусім звернемося до Закону України «Про засади запобігання та протидії дискримінації в Україні», який визначає організаційно-правові засади запобігання та протидії диск римінації задля забезпечення рівних можливостей щодо реалізації прав і свобод людини та громадянина. Експерти незалежної міжнародної організації "The Equal Rights Trust", метою якої $\epsilon$ протидія дискримінації та просування рівності як засадничого права людини та основного принципу соціальної справедливості, позначили цей Закон як «стислий рамковий», прийнятий «задля дотримання одного 3 критеріїв, викладених у Плані дій з лібералізації візового режиму «Україна - ЄС»». Експерти констатують, що початково цей Закон не враховував зауваження $€ C$, експертів P€ та міжнародних й українських неурядових організацій і містив певні прогалини й недоліки, на які було вказано експертами. У 2014 році в нього були внесені суттєві зміни, однак окремі зауваження в експертному середовищі залишилися [3, с. 273]. На наш погляд, деякі з них є дискусійними. 
Так, C. Ahlund та W. Sorgdrager вказали на те, що у цьому Законі викладено як загальне визначення дискримінації, так і окремі визначення прямої та непрямої дискримінації. Вказуючи на це як на недолік, експерти виходили з того, що «міжнародне право та найкращі практики наполягають на тому, що дискримінація мусить бути визначена як «пряма» або «непряма»», а загальне ії̈ визначення «як такої спричиняє ризики плутанини та помилкового тлумачення» [3, с. 275]. Підхід, реалізований вітчизняним законодавцем, однак, не суперечить міжнародним актам, які ми проаналізували у попередніх параграфах, у яких закріплено передусім загальне розуміння дискримінації. До того ж, як зазначають самі експерти, визначення п'яти заборонених форм дискримінації практично ідентичні до визначень, закріплених у різних директивах ЄС щодо боротьбі з дискримінацією [3, с. 275].

У цьому Законі визначено такі форми дискримінації (ст. 5), як пряма дискримінація; непряма дискримінація; підбурювання до дискримінації; пособництво у дискримінації; утиск. Причому позиції 3-5 були відредаговані у 2014 році. У контексті нашого дослідження важливою є ст. 8 цього Закону, відповідно до якої під час розроблення проєктів нормативно-правових актів обов'язково враховується принцип недискримінації; у процесі нормотворення передбачено проведення антидискримінаційної експертизи; її результати обов'язково розглядаються під час прийняття рішення про видання (прийняття) відповідного нормативно-правового акта. У цьому документі викладено перелік суб'єктів, уповноважених у сфері запобігання та протидії дискримінації (Верховна Рада України; Уповноважений Верховної Ради України з прав людини; Кабінет Міністрів України; інші державні органи, органи влади АРК, органи місцевого самоврядування; громадські організації, фізичні та юридичні особи), окреслено обсяг відповідних повноважень, а також відповідальність за порушення законодавства про запобігання та протидію дискримінації [27].

Задля досягнення паритетного становища жінок і чоловіків у всіх сферах життєдіяльності суспільства було прийнято Закон України «Про забезпечення рівних прав та можливостей жінок і чоловіків», чим закладено правову основу забезпечення рівних прав та можливостей цих категорій осіб, ліквідації дискримінації за ознакою статі. Актуальність цього Закону підтверджується тим, 
що жінки, як зазначено у звіті/доповіді «Вирішення проблеми дискримінації та нерівності в Україні», «є головними жертвами дискримінації за ознакою статі в Україні», що значною мірою «€ наслідком збереження патріархальних і патерналістських соціальних норм». У загаданому звіті також зазначено, що в Україні сформована міцна правова база щодо заборони дискримінації за ознакою статі, водночас діють нормативноправові акти, які містять пряму дискримінацію щодо жінок, або такі, що, «нібито прагнучи їх «захистити», насправді обмежують їх здатність робити вибір, особливо у сфері зайнятості». Непоодинокими $\epsilon$ випадки дискримінації жінок під час прийому на роботу, сексуальних домагань на робочому місці, нерівної порівняно з чоловіками оплати праці. Незважаючи на спеціальне кримінальне законодавство, високим також залишається рівень побутового насильства та торгівлі жінками [3, с. 66].

У Законі України «Про забезпечення рівних прав та можливостей жінок і чоловіків» визначено поняття «дискримінація за ознакою статі», виходячи з якого, можемо виокремити відповідні ознаки цього явища. Отже, цей тип дискримінації позначається тим, що спрямовується на окремих осіб та/або групу осіб за ознаками статі, що були, $\epsilon$ та можуть бути дійсними або припущеними. Дискримінація за ознакою статі - це ситуація, за якої ці особи та/або група осіб зазнають обмеження у визнанні, реалізації або користуванні правами й свободами або привілеями. Форми таких обмежень установлені в ст. 5 Закону України «Про засади запобігання та протидії дискримінації в Україні», крім випадків, коли такі обмеження або привілеї мають правомірну, об'єктивно обгрунтовану мету, способи досягнення якої $\epsilon$ належними й необхідними. Цей Закон відповідає міжнародним, у тому числі європейським, стандартам щодо ліквідації дискримінації за ознакою статі, зокрема пропагує модель «дійсної рівності». Нині законодавець уводить поняття гендерної рівності як рівного правового статусу жінок і чоловіків та рівних можливостей для його реалізації, що дає змогу особам обох статей брати рівну участь у всіх сферах життєдіяльності суспільства. Утвердження гендерної рівності та недопущення дискримінації за ознакою статі віднесено у ст. 3 цього Закону до основних напрямів державної політики щодо забезпечення рівних прав та можливостей жінок і чоловіків. Відповідно до ст. 6, дискримінація за ознакою статі забороняється [25]. 
Антидискримінаційні положення містить також Закон України «Про зайнятість населення», у ст. 11 якого закріплено право особи на захист від проявів дискримінації у сфері зайнятості населення. Відповідно до ч. 1 цієї статті, «держава гарантує особі право на захист від будь-яких проявів дискримінації у сфері зайнятості населення за ознаками раси, кольору шкіри, політичних, релігійних та інших переконань, членства у професійних спілках або інших об'єднаннях громадян, статі, віку, етнічного та соціального походження, майнового стану, місця проживання, за мовними або іншими ознаками». Згідно 3 ч. 3 цієї ж статті, «забороняється в оголошеннях (рекламі) про вакансії зазначати обмеження щодо віку кандидатів, пропонувати роботу лише жінкам або лише чоловікам, за винятком специфічної роботи, яка може виконуватися виключно особами певної статі, висувати вимоги, що віддають перевагу одній із статей, а також вимагати від осіб, які працевлаштовуються, надання відомостей про особисте життя» [26].

Вектор розвитку вітчизняного антидискримінаційного законодавства, зокрема щодо забезпечення ще більш повної його узгодженості з міжнародними, у тому числі європейськими, актами щодо запобігання та протидії дискримінації, визначено уПлані дій уряду з реалізації Національної стратегії у сфері прав людини на 2021-2023 роки [28]. Відповідні заходи можемо структурувати/згрупувати залежно від сфери суспільних відносин, в якій ці заходи покликані усунути прояви дискримінації.

Так, у сфері правосуддя заплановано розробити й подати на розгляд Кабінету Міністрів України законопроєкт, спрямований на вирішення системної проблеми щодо надмірної тривалості кримінального й цивільного провадження та обгрунтування відповідних ефективних засобів юридичного захисту (п. 22); забезпечити процесуальні права осіб з інвалідністю, зокрема щодо надання документів та інших матеріалів справи в електронному форматі (п. 23); розробити й подати на розгляд Кабінету Міністрів України проєкт Закону України «Про юстицію, дружню до дитини» та визначити у процесуальному законодавстві спеціальні процедури здійснення правосуддя щодо неповнолітніх (п. 67); розробити законопроєкт про внесення змін до Закону України «Про судоустрій і статус суддів» щодо введення до складу місцевих загальних судів та апеляційних судів таких суддів, які спеціалізуються на розгляді справ, що виникають із сімейних правовідносин і стосуються захисту прав та законних інтересів дітей (п. 70) тощо. 
У сфері трудових відносин заплановано розробити й подати на розгляд Кабінету Міністрів України законопроєкти про покладання на роботодавця обов'язку доказування в суді правомірності рішення, дії чи бездіяльності роботодавця у справах про дискримінацію у сфері праці (п. 31); про внесення змін до Закону України «Про Дисциплінарний статут Національної поліції України» задля включення положень про запобігання випадкам дискримінації за ознакою статі і сексуальних домагань на робочому місці (п. 32); про усунення дискримінаційних положень, які можуть порушувати права (майнові та немайнові) партнерів, котрі не перебувають у шлюбі, і про впровадження інституту зареєстрованого цивільного партнерства (п. 33); про внесення змін до Кодексу законів про працю України, Законів України «Про оплату праці», «Про забезпечення рівних прав та можливостей жінок і чоловіків», «Про колективні договори і угоди» задля зменшення різниці в оплаті праці жінок і чоловіків (п. 34). Крім того, заплановано розроблення й затвердження методичних рекомендацій щодо проведення гендерного аудиту підприємствами, установами та організаціями (п. 35).

У сфері соціального захисту передбачено такі заходи: переглянути державний стандарт соціального супроводу сімей (осіб), які перебувають у складних життєвих обставинах, з урахуванням положень Закону України «Про соціальні послуги» (п. 51); розробити й подати на розгляд Кабінету Міністрів України законопроєкт, у якому відповідно до міжнародних стандартів визначено поняття «підлітки» та «підлітки групи ризику» як вікової групи від 10 до 18 років включно (п. 52), законопроєкт про соціальну підтримку дітей, які постраждали внаслідок воєнних та збройних конфліктів (п. 71); розробити методичні рекомендації щодо надання дітям, розлученим із сім'єю, які не є громадянами України, дітям-біженцям, дітям, які потребують додаткового захисту, такої соціальної послуги, як соціально-психологічна реабілітація (п. 74); розробити законопроєкт про внесення змін до Закону України «Про запобігання та протидію домашньому насильству» (п. 41).

У сфері охорони здоров'я, крім іншого, заплановано на основі принципів міжнародної класифікації функціонування, обмежень життєдіяльності та здоров'я розробити чіткі критерії встановлення інвалідності (п. 58).

У сфері освіти заплановано розробити проєкти постанов Кабінету Міністрів України щодо типології/переліку категорій 
освітніх труднощів в осіб з особливими освітніми потребами з огляду на рівень підтримки в освітньому процесі в інклюзивних класах/групах закладів освіти (п. 63); щодо організації інклюзивного навчання в закладах загальної середньої освіти (п.66); розробити й подати на розгляд Кабінету Міністрів України законопроєкт про внесення змін до Закону України «Про освіту» щодо вдосконалення законодавства з протидії булінгу стосовно удосконалення суб'єктного складу учасників булінгу (п. п. 68-69); законодавчо закріпити критерії та індикатори щодо дотримання прав людини в освітньому процесі, які слід враховувати під час проведення інституційного аудиту в закладах загальної середньої освіти (п. 91).

Передбачено комплекс заходів задля удосконалення законодавства щодо забезпечення прав та свобод різних категорій осіб, які перебувають на тимчасово окупованих територіях України, $є$ внутрішньо переміщеними особами, постраждали внаслідок збройної агресії Російської Федерації проти України (стосується, зокрема, «множинної дискримінації») (п. п. 71-88).

Заплановано заходи щодо унеможливлення дискримінації за ознакою національної приналежності, зокрема удосконалити нормативно-правове регулювання реалізації прав національних спільнот (п. 47); розробити й подати на розгляд Кабінету Міністрів України проєкт Закону України «Про корінні народи в Україні» (п. 46).

Введення низки антидискримінаційних приписів передбачено в Кримінальний кодекс та Кримінальний процесуальний кодекс України (п. п. 1, 4 тощо), Кодекс України про адміністративні правопорушення (п. 14). Пунктом 28 Плану дій передбачено розроблення законопроєкту про внесення змін до Кримінального кодексу України, зокрема, щодо уніфікації використання терміна «нетерпимість» та обов'язкового врахування мотивів нетерпимості за такими ознаками, як колір шкіри, раса, національна або етнічна належність, релігійні та/або ідеологічні переконання, сексуальна орієнтація, гендерна ідентичність, інвалідність, мова, місце проживання, інші ознаки в разі призначення покарання за злочин. 


\section{Висновки}

Отже, дискримінація - це неправове обмеження прав особи за умов відсутності його розумного виправдання та неспівмірності з метою у зв'язку з віком, статтю, кольором шкіри, політичними чи релігійними переконаннями, соціальним станом, іншими ознаками особи/груп осіб, що постають як підстави дискримінації. Елементами дискримінації $\epsilon$ відмінне ставлення будь-якого прояву; негативний характер; завдання суб'єкту шкоди; значуща ознака, яка в конкретній ситуації постає як дискримінаційна; відсутність суспільно необхідної мети. Сутність принципу недискримінації полягає в тому, що незалежно від певних ознак осіб та/або груп осіб їм має бути забезпечено рівність прав та свобод; рівність перед законом; повагу до гідності кожної людини; рівні можливості. Значною мірою сутність принципу недискримінації збігається із змістом поняття «заборона дискримінації».

Антидискримінаційне законодавство України - це систематизована сукупність (система) актів різного правового характеру, а саме вітчизняних нормативно-правових актів різної юридичної сили (Конституція України, Закони України, підзаконні акти) та міжнародних документів, ратифікованих Україною. В Основному Законі України не використовується термін «дискримінація», однак прямо вказується на недопустимість привілеїв та обмежень, що загалом відповідає міжнародним актам у сфері прав людини щодо рівності та недискримінації.

Як складник системи національного антидискримінаційного законодавства міжнародні акти утворюють узгоджений комплекс, який охоплює документи ООН (Загальна декларація прав людини, Конвенції, Хартії); акти Ради Європи (ЄКПЛ та Протокол № 12 до неї, інші Конвенції); акти ЄС (антидискримінаційні директиви, Хартія основних прав $(\mathrm{C})$. Особливе місце в цьому комплексі посідає практика ЄСПЛ, врахування якої $€$ обов'язковим для національних судів у процесі розгляду справ відповідної категорії. У сукупності акти ООН та європейське антидискримінаційне право $\epsilon$ підгрунтям для вдосконалення вітчизняних нормативноправових актів щодо запобігання та протидії дискримінації, визначають вектор подальшого розвитку й удосконалення відповідного законодавства для ефективного запобігання та протидії дискримінації у сферах правосуддя, освіти, охорони здоров'я, соціального захисту, захисту прав національних меншин, жінок, дітей тощо. 


\section{Список використаних джерел:}

1. Академічний тлумачний словник : словник української мови : в 11 т. Т. 2. Київ : Наукова думка, 1971. 550 с.

2. Бачинська О.-М. Співвідношення принципів недискримінації та рівності у праві. Підприємництво, господарство і право. 2017. № 9. С. 165-168.

3. Вирішення проблеми дискримінації та нерівності в Україні. The Equal Rights Trust Country Report Series. Лондон, 2015. 473 с. URL: http://surl.li/aagse.

4. Дашковська О.Р. Міжнародні механізми забезпечення принципу недискримінації. Актуальні проблеми сучасного міжнародного права : збірник наукових статей за матеріалами I Харківських міжнародно-правових читань, присвячених пам'яті професорів М.В. Яновського і В.С. Семенова (Харків, 27 листопада 2015 року) : у 2 ч. Харків, 2015. Ч. 1. С. 119-127.

5. Декларація про ліквідацію всіх форм нетерпимості та дискримінації на основі релігії чи переконань : ООН ; Резолюція від 25 листопада 1981 року. URL: http://surl.li/aallu (дата звернення: 20.07.2021).

6. Додатковий протокол до Конвенції про кіберзлочинність, який стосується криміналізації дій расистського та ксенофобного характеру, вчинених через комп'ютерні системи / Рада Європи ; Протокол від 28 січня 2003 року. URL: http://surl.li/aaefa (дата звернення: 20.07.2021).

7. Європейська соціальна хартія : Рада Європи ; Хартія від 3 травня 1996 року. URL: http://surl.li/xano (дата звернення: 19.07.2021).

8. Загальна Декларація прав людини : ООН ; Декларація від 10 грудня 1948 року. URL: http://surl.li/umvi (дата звернення: 19.07.2021).

9. Калмикова О.С. Правова природа принципу недискримінації особистості. Право та інновації. 2015. № 4 (12). С. 151-156.

10. Ковальчук В.Б. Громадянські права і свободи людини як основний критерій легітимності та конституційності державної влади. Вісник Національного університету «Львівська політехніка». Серія: Юридичні науки. 2017. Вип. 876. № 1. С. 329-337.

11. Ковбасюк С. Напрями інституалізації недискримінації в Україні. Підприємнищтво, господарство і право. 2019. № 12. C. 259-265. 
12. Конвенція про захист прав людини і основоположних свобод : Рада Європи; Конвенція, Міжнародний документ від 4 листопада 1950 року. URL: http://surl.li/aaefd (дата звернення: 19.07.2021).

13. Конвенція про права осіб з інвалідністю : ООН ; Конвенція від 13 грудня 2006 року. URL: http://surl.li/yima (дата звернення: 18.07.2021).

14. Конвенція Ради Європи про доступ до офіційних документів : Конвенція від 18 червня 2009 року. URL: http://surl.li/aaeff https://zakon.rada.gov.ua/laws/show/994_858Text (дата звернення: 19.07.2021).

15. Конвенція Ради Європи про заходи щодо протидії торгівлі людьми : Рада Європи ; Конвенція, Міжнародний документ від 16 травня 2005 року. URL: http://surl.li/aaefi (дата звернення: 19.07.2021).

16. Конвенція про боротьбу з дискримінацією в галузі освіти : ООН ; Конвенція від 14 грудня 1960 року. URL: http://surl.li/aalnn (дата звернення: 19.07.2021).

17. Конвенція щодо дискримінації в галузі праці та занять : МОП ; Конвенція від 25 червня 1958 року № 111. URL: http://surl.li/aalkx (дата звернення: 19.07.2021).

18. Конституція України : Верховна Рада України ; Закон від 26 червня 1996 року № 254к/96-BP. URL: http://surl.li/gdyl (дата звернення: 16.07.2021).

19. Лемак В., Бадида А. Позитивні зобов'язання держави в контексті розуміння прав людини. Публічне право. 2017. № 2 (26). С. 245-253.

20. Міжнародна конвенція про ліквідацію всіх форм расової дискримінації : ООН ; Декларація від 21 грудня 1965 року. URL: https://zakon.rada.gov.ua/laws/show/995_105\#Text (дата звернення: 20.07.2021).

21. Панкевич 0.3. Захист права людини на недискримінацію у практиці Європейського Суду з прав людини. Науковий вісник Львівського державного університету внутрішніх справ. 2016. № 3. С. 325-335.

22. Порадник із запобігання та протидії дискримінації (Рада Європи). Київ : ФЕНІКС, 2018. 390 с.

23. Посібник з європейського антидискримінаційного права. Українське видання : ТОВ «К.I.С.», 2013. 196 с. 
24. Про виконання рішень та застосування практики Європейського суду з прав людини : Закон України від 23 лютого 2006 року № 3477-IV. URL: https://zakon.rada.gov.ua/laws/ show/3477-15\#Text (дата звернення: 20.07.2021).

25. Про забезпечення рівних прав та можливостей жінок i чоловіків : Закон України від 8 вересня 2005 року № 2866-IV. URL: http://surl.li/rclw (дата звернення: 18.07.2021).

26. Про зайнятість населення : Закон України від 5 липня 2012 року № 5067-VI. URL: http://surl.li/aalur (дата звернення: 16.07.2021).

27. Про засади запобігання та протидії дискримінації в Україні : Закон України від 6 вересня 2012 року № 5207-VI. URL: http://surl.li/aaijd (дата звернення: 18.07.2021).

28. Про затвердження Плану дій з реалізації Національної стратегії у сфері прав людини на 2021-2023 роки : Кабінет Міністрів України ; Розпорядження від 23 червня 2021 року № 756-p. URL: http://surl.li/aagip (дата звернення: 16.07.2021).

29. Про міжнародні договори України : Закон України від 29 червня 2004 року № 1906-IV. URL: http://surl.li/aaefj (дата звернення: 17.07.2021).

30. Про Національну Стратегію у сфері прав людини : Указ Президента України ; Стратегія від 24 березня 2021 року № 119/2021. URL: https://zakon.rada.gov.ua/laws/show/119/2021 (дата звернення: 16.07.2021).

31. Протокол № 12 до Конвенції про захист прав людини i основоположних свобод : Рада Європи ; Протокол від 4 листопада 2000 року. URL: http://surl.li/aaefk (дата звернення: 19.07.2021).

32. Равлінко 3.П. Заборона дискримінації: загальнотеоретичне дослідження : дис. ... канд. юрид. наук : спец. 12.00.01. Львів, 2016. $201 \mathrm{c}$.

33. Рамкова Конвенція про захист національних меншин : Рада Європи ; Конвенція, Міжнародний документ від 1 лютого 1995 року. URL: http://surl.li/aaefo (дата звернення: 19.07.2021).

34. Рябовол Л.Т. Конституційно-правовий статус людини і громадянина: особливості регулювання та закріплення в зарубіжних країнах. Актуальні правові і гуманітарно-економічні проблеми в період реформування демократичного суспільства : матеріали V Всеукраїнської науково-практичної конференції (Кропивницький, 24 листопада 2017 року). Кропивницький, 2017. С. 174-177. 
35. Рябовол Л.Т. Обмеження прав та свобод людини i громадянина як соціокультурний та політико-правовий феномен. Право, суспільство і держава: форми взаємодії : матеріали міжнародної науково-практичної конференції (Київ, 12-13 січня 2018 року). Київ : Центр правових наукових досліджень, 2018. C. 17-20.

36. Рябовол Л.Т. Система законодавства про наукову i науково-технічну діяльність. Наукові записки. Серія: Право. 2018. Вип. 5. С. 4-10.

37. Рябовол Л.Т. Система законодавства про правову освіту населення України. Порівняльно-аналітичне право. 2016. № 4. С. 38-41.

38. Троян В.А. Права і свободи людини та інтереси держави як об’єкт публічно-сервісної діяльності Національної поліції України. Вісник кримінологічної асоціації України. 2017. № 1 (17). С. 229-239.

39. Фокіна М.О. Права i свободи людини як об’єкт конституційно-правового регулювання : автореф. дис. ... канд. юрид. наук : спец. 12.00.02. Харків, 2016. 20 с.

40. Хартія основних прав Європейського Союзу : Європейський Союз ; Хартія від 7 грудня 2000 року. URL: http://surl.li/aaefm (дата звернення: 18.07.2021).

41. Христова Г.О. Позитивні обов'язки держави у сфері протидії дискримінації. Вісник Національної академії правових наук України. 2013. № 4 (75). С. 11-20. 